\title{
HUDHUD CYCLONE - A SEVERE DISASTER IN VISAKHAPATNAM
}

\author{
Kolli Ramuje ${ }^{1}$, B.Naga Malleswara Rao ${ }^{2}$
}

\author{
${ }^{I}$ Associate Professor, Department of Civil Engineering, VNR Vignana Jyothi Institute of Engineering \& Technology, \\ Hyderabad \\ ${ }^{2}$ Professor \& Head, Department of civil Engineering, VNRVJ Institute of Engineering \& Technology, Bachupally, \\ Hyderabad-500090
}

\begin{abstract}
Andhra Pradesh is a coastal state on East coast of India. It has been traditionally vulnerable to natural disasters on account of its unique geo-climatic conditions. The Geo-physical location of state along the eastern coast of India has made it vulnerable to Tropical cyclones generated by bay of Bengal. Natural disasters are the most frequent in the state and crores of rupees are lost. Natural disaster is a matter of major concern for a state whose more than $60 \%$ of population lie below poverty line. An attempt is made in this paper to review the a major disaster i.e cyclones that frequently occurs in Andhra Pradesh, causes, effects, coping strategies and disaster management plan with a special reference to the recently hit Hudhud cyclone in Visakhapatnam.
\end{abstract}

Keywords: Geo-physical, Tropical cyclones, causes, effects, coping strategies and disaster management plan

\section{INTRODUCTION}

The cyclone disasters are major challenges and these are to be effectively addressed and efficiently managed in order to have sustainable development and poverty alleviation particularly in developing countries like India. One third of the natural disasters are in the world can be attributed due to cyclone events. Globally, cyclones and tropical storms are the most expensive hazards during the last 100 years[1]. Tropical cyclones in particular are the most devastating on natural disasters due to the loss of human life they cause and economic losses they induce. "A non frontal synoptic scale low pressure system originating over tropical or sub tropical waters with organized convection and definite cyclonic surface wind circulation" is called a tropical cyclone[2].

\section{PROFILE OF ANDHRA PRADESH}

Andhra Pradesh has three regions which are distinct in terms of socioeconomic characteristics and have region specific resource base. Of the twenty-three districts, nine are in Coastal Andhra region; ten in Telangana region and four in Rayalaseema region. Andhra Pradesh (A.P.) is highly prone to natural disasters. Floods and cyclones are a recurrent phenomenon in Andhra Pradesh. Susceptibility to disasters is compounded by frequent occurrences of manmade disasters such as fire, industrial accidents etc. While accurate data is in the process of being collated and analyzed; recent floods in Kurnool and other coastal districts in October-November 2009 have reversed the development growth experienced by Andhra Pradesh in the last decade. Frequent disasters lead to erosion of development gains and restricted options for the disaster victims. Physical safety, especially of the vulnerable groups, is routinely threatened by natural hazards. Recent floods in A.P. have very clearly illustrated the need for multi-hazard prevention, response and recovery plans for natural hazards so that threat to human life and property is minimized.

\section{HISTORY OF CYCLONES IN ANDHRA PRADESH}

In peninsular India, cyclones occur frequently on both the coasts i.e. The West Coast (Arabian Sea) and East Coast (Bay of Bengal). But the East Coast is considered to be one of the most cyclone prone areas of the world. An analysis of the frequencies of cyclones on the East and West coasts of India during 1891- 1990 shows that nearly 262 cyclones occurred (92 severe) in a $50 \mathrm{~km}$ wide strip on the East Coast, Less severe cyclonic activity on West Coast amounting to 33 cyclones in the same period. About eighty tropical cyclones (with wind speeds equal to or greater than 35 knots) form in the world's waters every year. Of these about $6.5 \%$ develop in the Bay of Bengal and Arabian Sea. Since the frequency of cyclones in the Bay of Bengal is about 5 to 6 times the frequency of those in the Arabian Sea, the Bay of Bengal's share comes out to be about $5.5 \%$. The Bay of Bengal is one of the major centers of the world for breeding of tropical storms. Cyclones over the Bay of Bengal usually move westward or northward and cross the east coast of India or Bangladesh. When this happens, it brings strong winds and high rainfall to the coastal region, causing damage to property and loss of life[3].

Cyclones on the east coast originate in the Bay of Bengal, the Andaman Sea or the South China Sea, and usually reach the coastline of Tamil Nadu, Andhra Pradesh, Orissa and West Bengal, which are most vulnerable to this type of hazards. Two of the deadliest cyclones of this century,with fatalities of about 10,000 people in each case, took place in Orissa and Andhra Pradesh during October 1971 and November 1977 respectively. The super cyclone of Orissa in 1999 caused large scale damage to life and property. Along Andhra Pradesh coast, the section between Nizampatnam and Machilipatnam is most prone to storm surges. Vulnerability to storm surges is not uniform along Indian 
coasts. Andhra Pradesh coast between Ongole and Machilipatnam is recognized as vulnerable to high surges among the segments of the east coast. The Bay of Bengal accounts for seven percent of the annual tropical cyclone activity worldwide; the recorded frequency of cyclones per year along the Bay of Bengal is four and inevitably one of the four transforms into a severe cyclone causing human and property losses. Although the percentage of cyclonic activity along the coast is relatively low, the level of human and property loss that cyclones cause around the Bay is very high. Cyclonic landfall usually lead to heavy rains accompanied with high speed winds and eventually translate into floods, as was the case with the damaging cycloneinduced floods in the Godavari delta in August 1986. While the entire coast of Andhra Pradesh is vulnerable to Cyclones, nine districts identified in the map below are most vulnerable and have recorded some levels of landfall in the last century as shown in the table. 1

Table.1: Distribution of cyclones district wise crossing the AP Coast till 2009

\begin{tabular}{|l|l|l|l|}
\hline \multirow{2}{*}{ S.NO } & \multirow{2}{*}{ District } & \multicolumn{2}{l|}{ No cyclones crossing the state } \\
\cline { 3 - 4 } & & $\begin{array}{l}\text { Severe } \\
\text { cyclone }\end{array}$ & $\begin{array}{l}\text { Medium/normal } \\
\text { cyclone }\end{array}$ \\
\hline 1 & Nellore & 11 & 21 \\
\hline 2 & Krishna & 8 & 15 \\
\hline 3 & East Godavari & 4 & 11 \\
\hline 4 & Srikakulam & 4 & 10 \\
\hline 5 & Visakhapatnam & 3 & 7 \\
\hline 6 & Prakasam & 2 & 4 \\
\hline 7 & Guntur & 1 & 2 \\
\hline 8 & West Godavari & 0 & 0 \\
\hline 9 & Vijayanagaram & 0 & 0 \\
\hline
\end{tabular}

Source: APSDMP

The criteria followed by the Indian Meteorological Department to classify the low pressure systems in the Bay of Bengal and Arabian Sea as adopted from the World Meteorological Organization (W.M.O.) classifications are as given in the following table. 2

Table: 2 Classification of cyclones

\begin{tabular}{|l|l|l|}
\hline S.No & category & $\begin{array}{l}\text { Wind speed in } \\
\mathbf{k m} / \mathbf{h}\end{array}$ \\
\hline 1 & Super Cyclonic Storm & $\geq 222$ \\
\hline 2 & $\begin{array}{l}\text { Very Severe Cyclonic } \\
\text { Storm }\end{array}$ & 119 to 221 \\
\hline 3 & Severe Cyclonic Storm & 89 to 118 \\
\hline 4 & Cyclonic Storm & 62 to 88 \\
\hline 5 & Deep Depression & 50 to 61 \\
\hline 6 & Depression & 31 to 49 \\
\hline 7 & Low Pressure Area & $<31$ \\
\hline
\end{tabular}

Source: APSDMP

\section{HISTORY OF HUDHUD CYCLONE}

History of Hudhud cyclone was the second strongest tropical cyclone of 2014 within the North Indian Ocean, as well as the most destructive tropical cyclone in the basin since Nargis in 2008. Hudhud originated from a low pressure system that formed under the influence of an upper-air cyclonic circulation in the Andaman sea on October 6. Hudhud intensified into a cyclonic storm on October 8 and as a Severe Cyclonic Storm on October 9. Hudhud underwent rapid deepening in the following days and was classified as a Very Severe Cyclonic Storm by the IMD. Shortly before landfall near Visakhapatnam, Andhra Pradesh, on October 12, Hudhud reached its peak strength with three minute wind speeds of $175 \mathrm{~km} / \mathrm{h}(109 \mathrm{mph})$ and a minimum central pressure of 960 mbar $(28.35$ in $\mathrm{Hg}$ ). The system then drifted northwards towards Uttar pradesh and Nepal, causing widespread rains in both areas and heavy snowfall in the latter. ${ }^{[4][5]}$ Hudhud caused extensive damage to the city of Visakhapatnam and the neighbouring districts of Vizianagaram and Srikakulam of Andhra Pradesh. Damages are estimated to be at least $₹ 70000$ crore ${ }^{[6]}$ with assessments still underway. ${ }^{[7]}$ At least 109 deaths have been confirmed, a majority of them from Andhra Pradesh and Nepal, with the latter experiencing an avalanche due to the cyclone. 


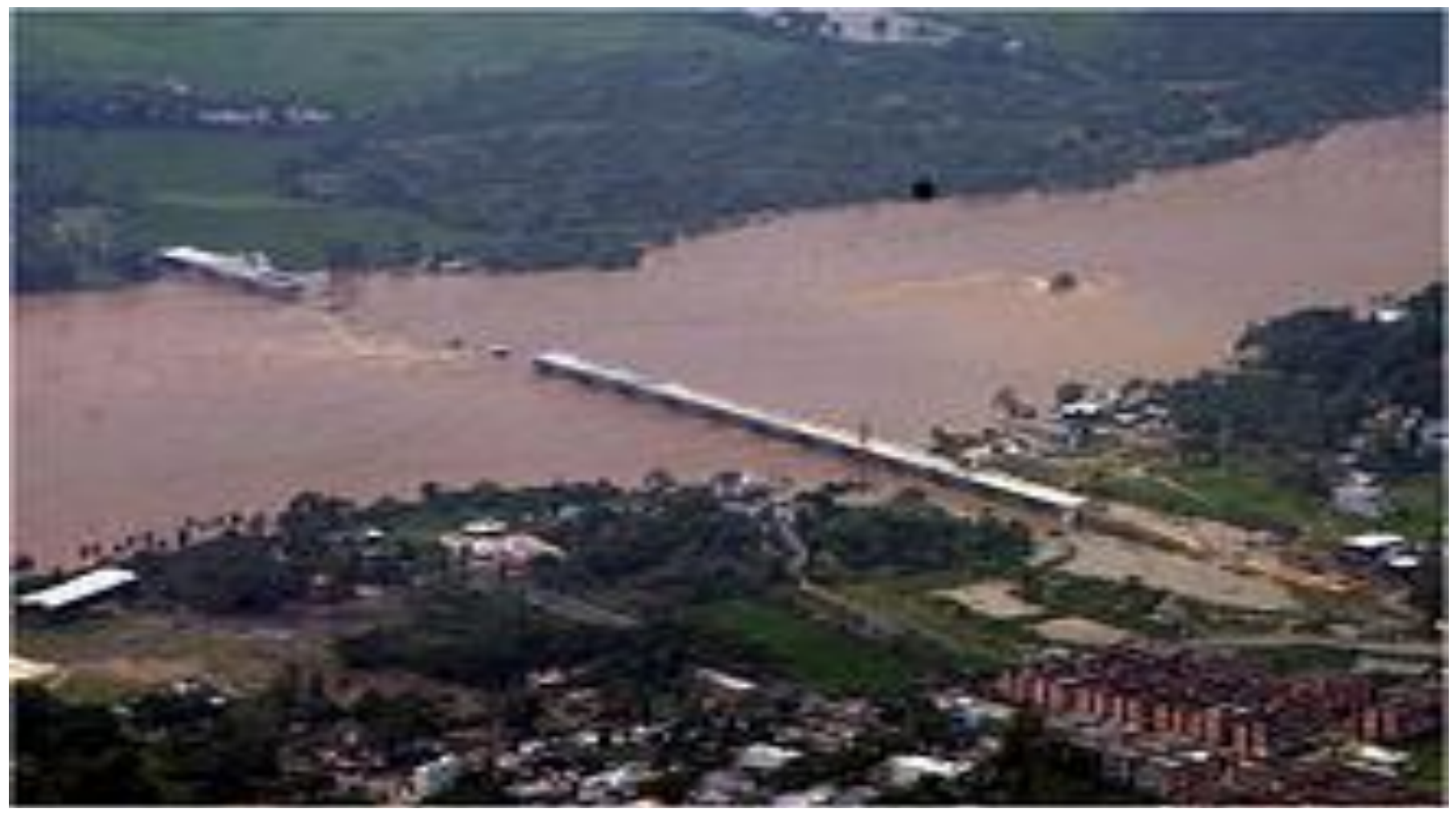

A Blown away bridge near Visakhapatnam:

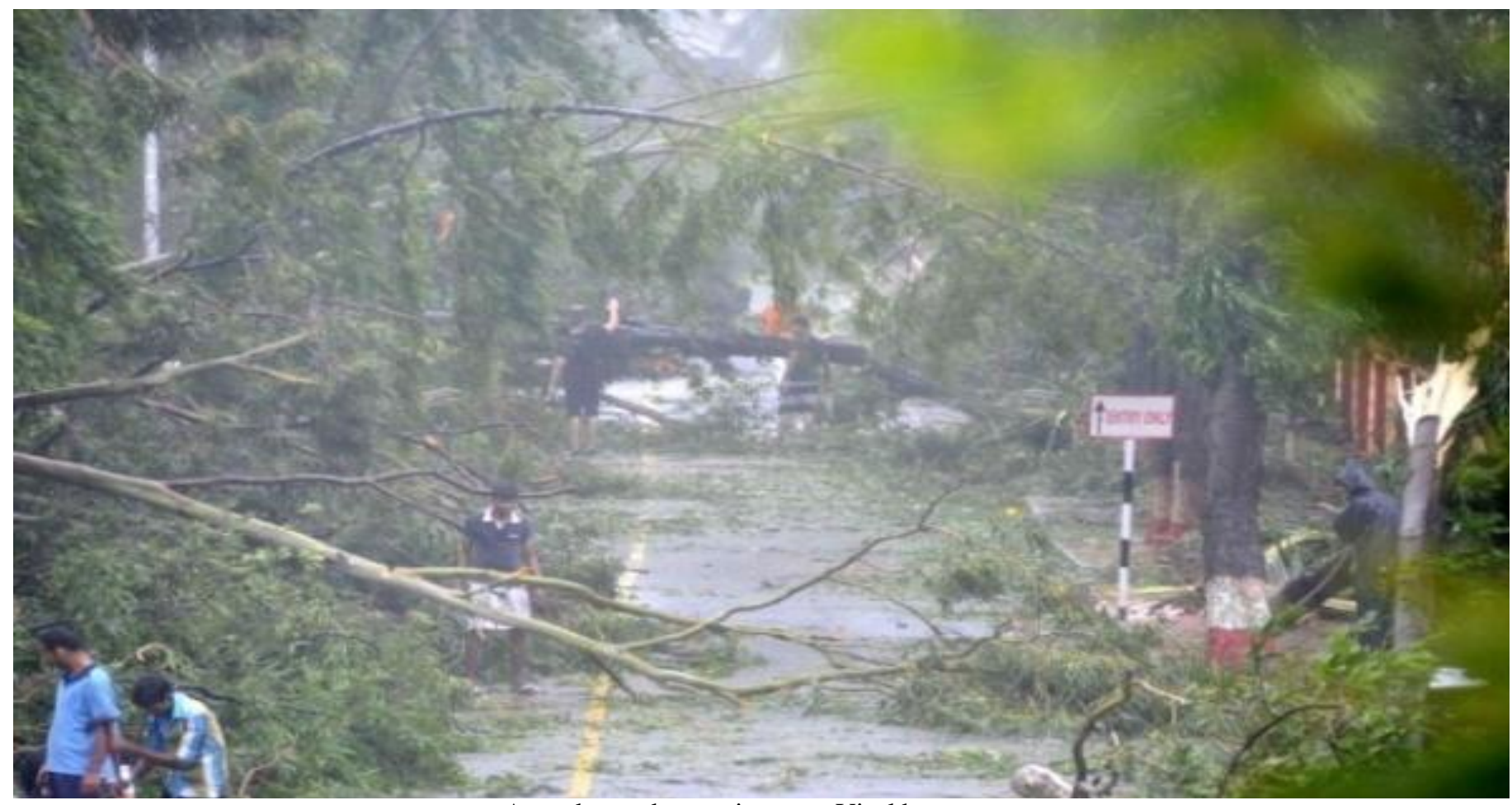

A road way destruction near Visakhapatnam 

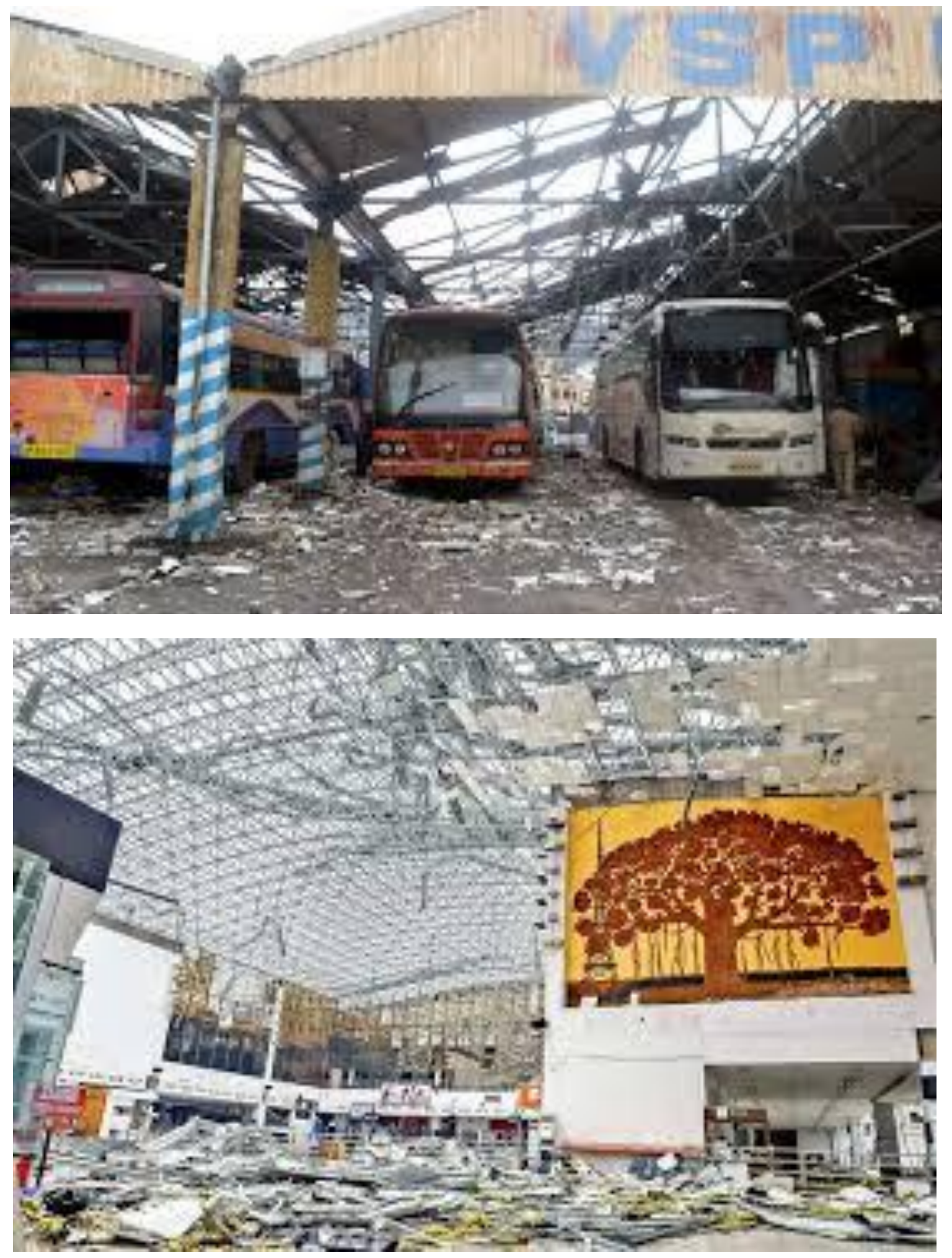

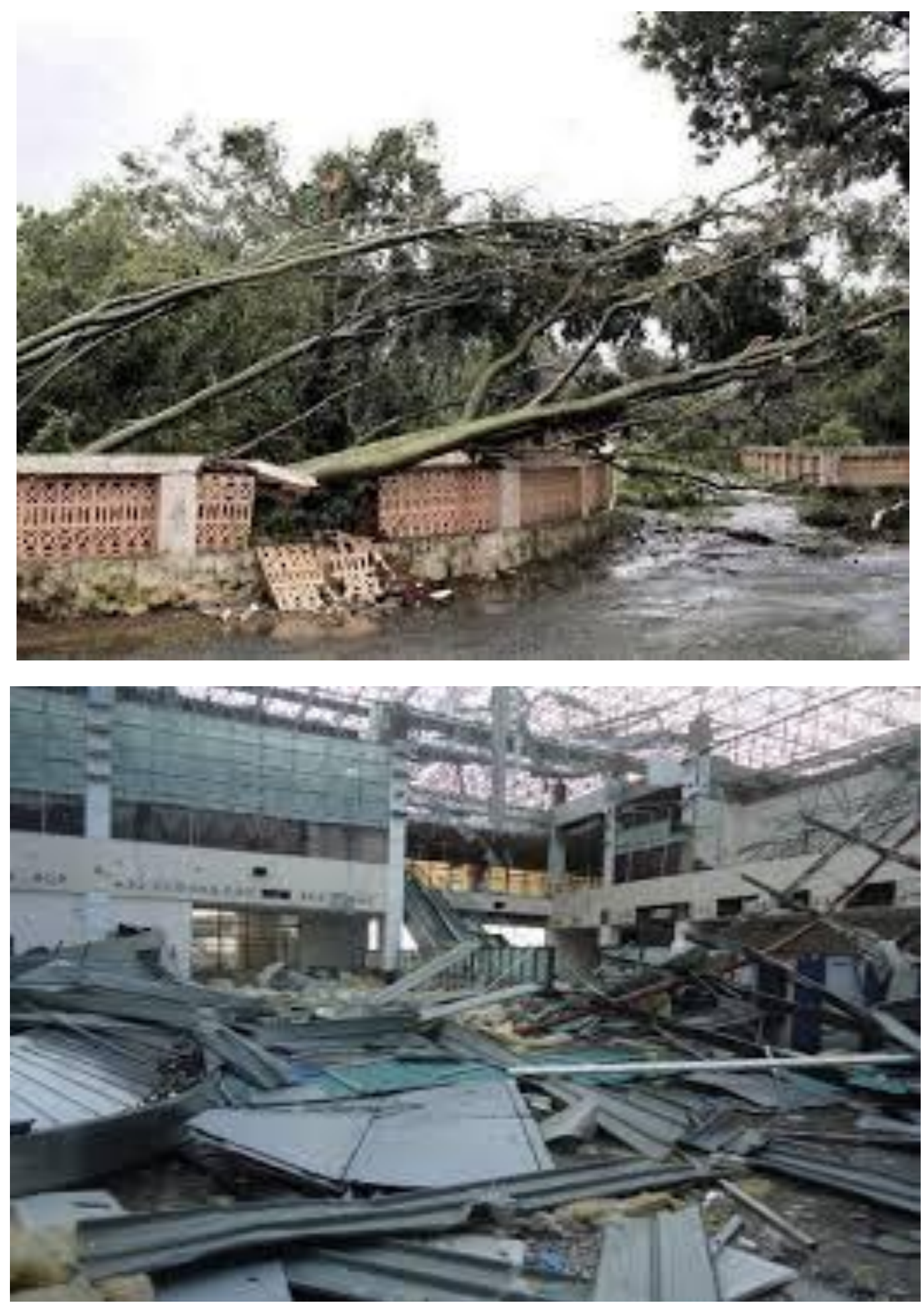

Images of Structural and non structural failures during the Hudhud cyclone in Vizag 

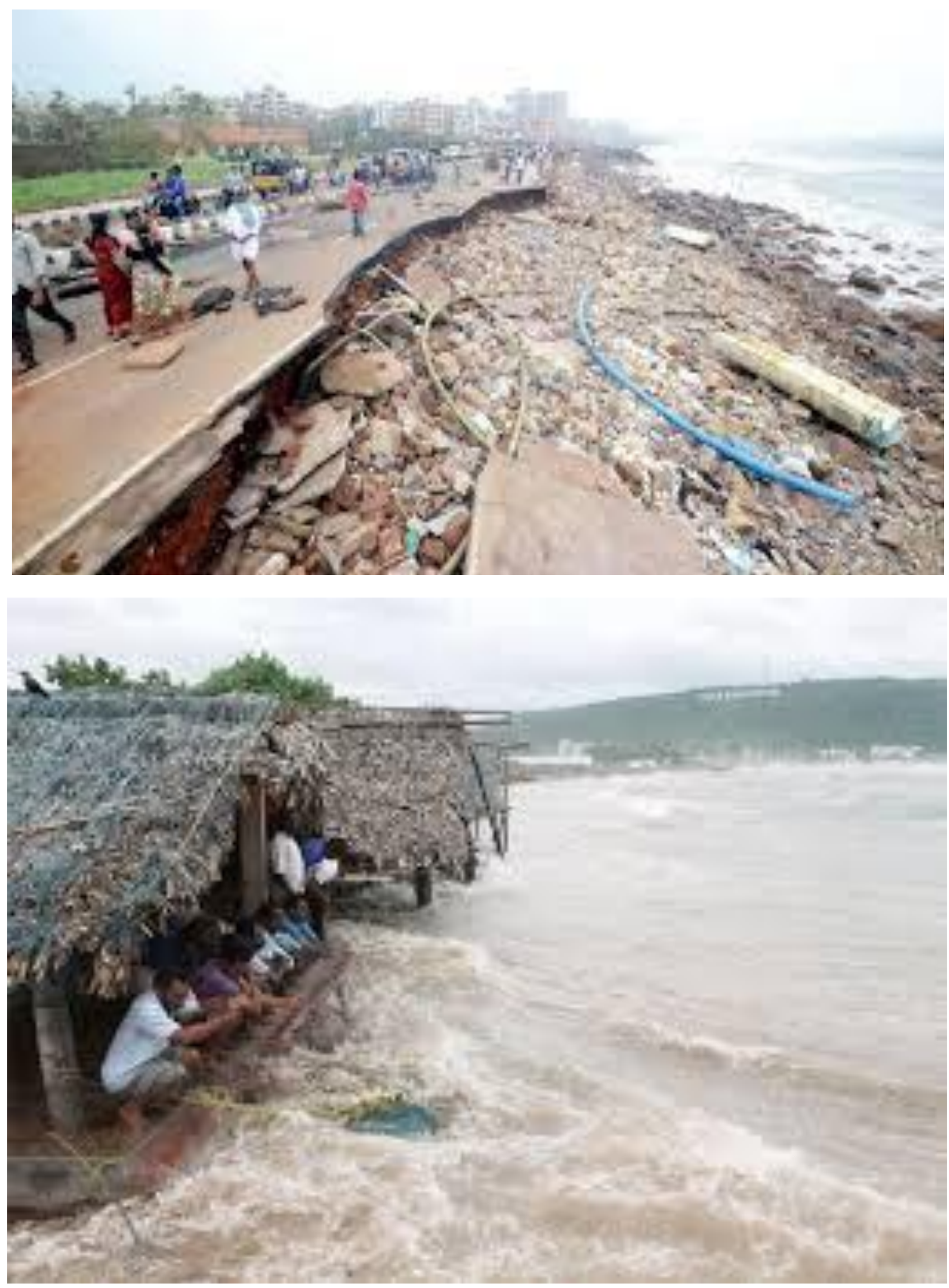


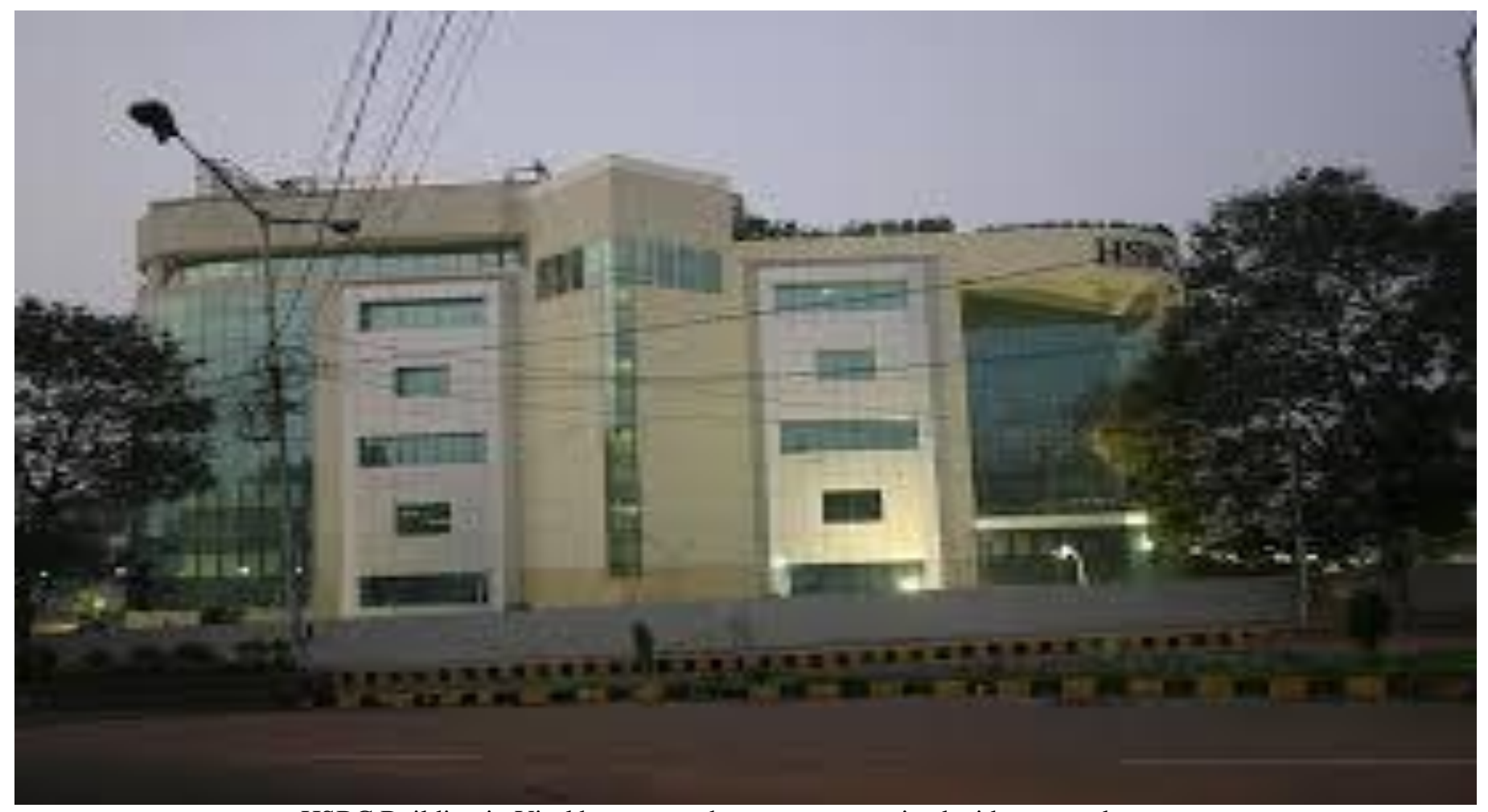

HSBC Building in Visakhapatnam, the structure servived without any damage

\section{EFFECTS OF HUDHUD CYCLONE:}

The cyclone, that made landfall in the Port City around noon witnessed the following

1)The hoardings and tin roofs flying like saucers, shattered windows leaving the streets littered with glass shreds, toppled over statues of leaders in many places as well as landmarks like the replica of the navy airplane on RK Beach.

2)Scores of electricity and telephone poles were knocked down and thousands of trees uprooted as strong gales accompanied by heavy rainfall lashed the city.

3) Paddy fields and fruit orchards spread over thousands of acres, and long stretches of roads in north coastal Andhra and East Godavari district were damaged in the heavy rain and winds brought by Cyclone Hudhud. Almost every household in the four affected districts suffered damage at least to some extent.

4) With heavy destruction of basic infrastructure in the region, industrial production and business transactions were badly hit. And with electricity unlikely to be restored in the next couple of days, officials fear more losses. Though the state government is yet to estimate the total loss, it is expected to be at least Rs 10,000 crore.

5) Reports of damage to hundreds of fishing boats have come in from Srikakulam, Vizianagaram, Visakhapatnam, and East Godavari districts.

6) Scores of communication towers were also uprooted by strong winds, disrupting telephone and mobile network. 7) Restoration works have been initiated on a war footing.

8) Hudhud slamming into the Vizag coast on Sunday morning, people faced anxious moments as their phones (both mobile and landline) went phut, cutting them off from their near and dear ones. By afternoon, when Hudhud made a landfall, most of the phone lines in the city either went dead or had only enough signal to send only SOS SMSes.

9) With the power discom switching off power supply from the early hours of Sunday in Visakhapatnam, Srikakulam and Vizianagaram districts, most of the telecom towers faced downtime.

10) 436 villages across 64 mandals in the five districts have been identified as exposed to the threat of cyclone. The government has identified 370 relief camps for the evacuated people in these districts 35,000 persons have been evacuated in Srikakulam district, 6,000 in Vizianagaram, 15,000 in Visakhapatnam, 50,000 in East Godavari and 5,000 in the West Godavari district.

\section{COPING STRATEGIES}

The importance of the need for serious consideration in the light of Hudhud

- Better use of channels of communication available by revamping the existing procedures.

- Establishing the direct communication between the $\mathrm{CWC}$ and the district head quarters to include VHF sets

- Need for interpretation of the messages at the district head quarters and prioritization of the tasks need to be done by various line departments based on the assessment of the warning messages

- Focusing on the vulnerable inaccessible villages in the affected areas for dissemination of warning and standby preparations for evacuation to be kept ready should cyclone change its course

- Increase awareness level in the officials and public 
- Increase the capacity of villages to receive warnings by other media channels over and above the dissemination through the revenue channel

\section{DISASTER MANAGEMENT PLAN}

The following may be some recommendations for improvement in disaster management plan.

- Emergency shelters should be properly maintained and more school should be earmarked for shelter purpose in future, While constructing new school building in disaster affected areas more fund should be allocated for additional safety measures in these buildings.

- NGOs,community based organizations should be integrated in the community disaster response and rehabilitation planning. A mechanism should be also be created to make NGOs accountable for all the aid received which could be done through initial identification of the NGOs and rating their work.

- It is necessary that warning should be more location specific and built up credibility in warning system.

- The organizations and institutes responsible for emergency response such as Army, police, hospital etc. in the vulnerable areas, disaster management drills should be taken regurly and seriously.Regural mock drill exercises, training and advance preparations of response plans in those organizations are essential elements for effective dealing in emergency situations.

- Research on disasters and reduction of their impact should be given priority and the output should be used in policy formulation and project selection.

- In ordered to prevent inappropriate construction of building,the building code should be strictly implemented.

- There is an urgent need to improve road infrastructure, transportation and communication facilities in disaster prone areas.

- $\quad$ Political determination and quick decision making is needed to carry out disaster management activities efficiently and effectively.

- Encourage shelterbelt plantation in coastal areas to reduce wind velocity.

- Disaster resistant crops should be encouraged to plant by farmers.

- Increase in population and increasing poverty have put a tremendous pressure in natural resources and the environment. Degradation of environment, disasters and poverty form a vicious cycle and this cycle can be overcome only by a careful environment management planning and integrating it with disaster management and poverty allevation.

- There should be a proper land use control and settlement policy in the state.

- Disasters, their impact on life and poverty and their management should be included In academic course from school level.

\section{CONCLUSION}

In the light of Pre and Post Hudhud cyclone effects, the Cyclone management in the Andhra pradesh is well coordinated and is executed with dedication by the all the members involved in the various operations. However, there is a need to be more pro-active before the hazard strikes, still requires to be given more attention and adequate funds should be earmarked for this purpose. There is a need to design the structures by the structural Engineers based on wind speed exceeding $70 \mathrm{~m} / \mathrm{s}$ in future in the light of Hudhud cyclone especially structures located in the coastal region of Andhrapradesh. It is recommended to encourage the shelter belt plantation along the coast to reduce the wind velocity and disaster resistant crops should be encouraged to plant by formers. Relief and mitigation expenditures on account of different calamities have to met out of Calamity relief fund at state level under the chairmanship of the chief minister for overall supervisions and monitoring at the state level.

\section{REFERENCES}

[1] Edward Bryant, "Natural hazards", Cambridge university press, 2005, second edition.

[2] Henderson A et al " Tropical cyclones and global climate change: A post-IPCC assessment”. Bulletin of the American meteorological society,1998, vol 92,pp 171-179.

[3] Andhra Pradesh State Disaster Management Plan (AP SDMP), revenue dept, vol 1, Aug 2010.India Meteorological Department. Retrieved 15 October 2014.

[4] "Nepal vows new safety rules for trekkers after deaths of 41 killed in blizzard, avalanches". 21 October 2014. Retrieved 22 October 2014

[5] "HUDHUD Relief Effort". Go Fund Me. 26 October 2014. Retrieved 27 October 2014.

[6] "Cyclone Hudhud impact: Death toll rises to 35 in Andhra Pradesh". Deccan Chronicle. 15 October 2014. Retrieved 15 October 2014

[7] The times of India, Retrieved 15 October 2014

[8] www.wickiepaedia.com

[9] D.V.Rao, "Disaster management in andhrapradeshCyclones" Proceedings of National conference on disaster prevention mitigation and management, October 2001.

[10] Akshaya kumar sabat et.al "Orissa and natural disaster" Proceedings of IC-NHDM -2007 , December 2007,pp 33-40.

[11] B V Ramana Prasad “ Review of Indian Tropical cyclones-A global Perspective, Proceedings of ICNHDM -2007, December 2007,pp 66-74.

[12] www.google.com 